\title{
Resource Management in National Parks
}

\author{
by
}

\author{
Nikita Lopoukhine 1
}

\section{Introduction}

One hundred years ago the Canadian government set aside land centered on the Banff Hot Springs in the Rocky Mountains. Since Canada's national parks trace their origin to this event, it is being commemorated this year in the form of centennial activities throughout Canada. Every national and historic park has scheduled centennial events.

Currently there are 61 national historic parks and sites and 31 national parks. The national park's land area totals $140845 \mathrm{~km}^{2}$ which represents $1.5 \%$ of Canada. Although this is a small percentage the area is appreciable given that it exceeds the area of Canada's Maritime Provinces and that of countries such as Greece and Bulgaria. In 1984 over 25 million visits to Canada's parks were recorded. Every province and every territory contains at least one national park (Figure. 1). Nevertheless, the present configuration is considered deficient by system park planners since only 20 of the 39 Canadian terrestial natural regions are now represented by these parks.

In this the year of the national park system centennial it is appropriate to review the purposes of national parks and to present the framework for natural resource management within them and then touch on one of the major objectives, fire management. First, some historical notes are given on policy changes during the first hundred years. The changes mirror the evolution of Canadian views on the purpose of national parks and thus also the natural resource management objectives.

\section{Parks Policy in the Past}

Neither preservation nor conservation were the reasons for setting aside land in Banff 100 years ago; national pride and economics were the determinants. There was a desire to compete with American and even European vacation spas. Accordingly, tourism in Banff National Park was encouraged by permitting a variety of cultural activities and of course providing the necessary facilities. Other parks were established in the next two decades and these were likewise "improved" to meet the prevailing views of what belonged in a park. Resource management in the parks was not different from adjoining areas. Thus, beside recreation development, grazing, mining, and forestry were permitted (however, not without some protest even in 1887).
Responsibility for parks resided initially with the Superintendant of Forestry, the senior official of the Forestry Branch of the Department of the Interior. The 1911 Dominion Forestry Reserves and Parks Act established the National Parks Branch. Ironically it was the forestry reserves under that act that came under guidelines of conservation. In contrast, within parks extermination of predators was actively pursued, fires were extinguished, hydroelectric power was developed, and exotic species were introduced.

Perceptions were changing however. In the 1929 annual report, Commissioner Harkin wrote ". . . the National Park movement was in its infancy, it was perhaps necessary to emphasize this aspect (economic) of their value, today, when this is so widely recognized it is perhaps permissable to point out that there are other values, equally if not more important in the long run." Accordingly, under his tutelage, proposed dams were not built, grazing permits were reduced in number, and one of the parks established during his tenure was specifically intended for the preservation of antelopes.

The 1930 National Park Act is an important milestone. Section 4 of the Act defined the purpose of national parks; "The parks are hereby dedicated to the people of Canada for the benefit, education and enjoyment, subject to the provisions of this act and the regulations, and such parks shall be maintained and made use of so as to leave them unimpaired for the enjoyment of future Canadians". By specifying use without abuse and by introducing the element of perpetuity this section of the Act provides the basic frame of reference for resource management in national parks.

However, because it is not specific, Section 4 has been subjected to various interpretations over the past 55 years. Each viewpoint has tried to capture the prevailing Canadian expectation for national parks. This has been particularly evident in the past 20 year as public participation in the planning of national parks became prominent. Three formal policy statements that interpret the act have been prepared to date. The latest was adopted by the federal Cabinet in 1979. The process of reviewing existing policies is an ongoing one. A major thrust for defining future Parks Canada policies is expected to come from the Heritage for Tomorrow Conference - National Assembly held in Banff this September. 


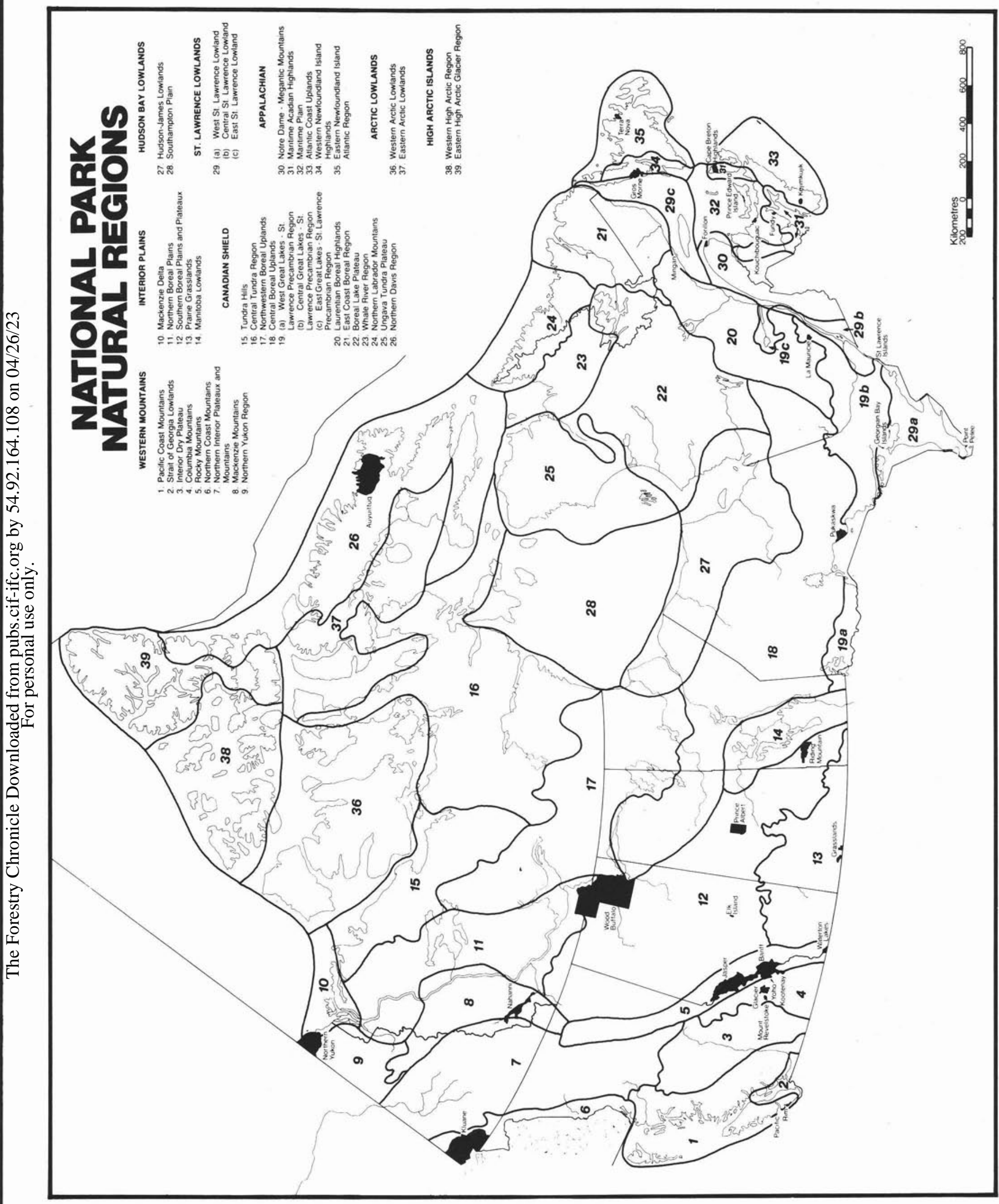




\section{Resource Management Framework}

Parks Canada Policy. The 1979 Parks Canada Policy covers all initiatives of the Parks Canada program. For national parks, the policy addresses such matters as research, the establishment of new parks, the use and enjoyment of parks, the zoning system, and of course the protection of natural resources including sections on resource management. The sections pertinent to resource management are reproduced below.

Section 3.2.1 Natural resources within national parks will be protected and managed with minimal interference to natural processes to ensure the perpetuation of naturally evolving land and water environments and their associated species.

Section 3.2.3 Manipulation of naturally occuring processes such as fire, insects and disease may take place only after monitoring has shown that:

a) there may be serious adverse effects on neighbouring lands; or

b) public health or safety is threatened; or

c) major park facilities are threatend; or

d) natural processes have been altered by man and manipulation is required to restore their natural balance; or

e) a major natural control is absent from the park; or

f) the continued existence of a plant or animal species, which is rare or endangered or which is critical to representation of the natural region, is threatened by a natural cause such as insects or disease; or

g) the population of an animal species or stage of plant succession which has been prescribed in the objectives for a park, cannot be maintained by natural forces.

Section 3.2.4 Where active resource management is necessary, techniques will duplicate natural processes as closely as possible.

Section 3.2.5 Resource management in each national park will take into account factors such as park size, objectives, zoning, geographic location and the nature of the activities occuring in surrounding area.

Parks Canada Directives. Specific objectives are achieved through the application of management directives. These, approved by the Assistant Deputy Minister, provide a detailed interpretation of the existing policy and specify what actions are to be taken, by whom and for what purpose. Examples of resource management directives are the Natural Resources Management Process and the Environmental Assessment and Review Process. Titles of more specific directives which are in the final approval stages include Fire Management, Bear Management, and Endangered Species.

The Natural Resources Management Process (NRMP) formalizes the methods by which natural resources are managed. In general the NRMP follows most traditional resource management approaches. Briefly, based on a plan, data are collected using holistic or integrated techniques commonly associated with the biophysical or ecological land classification methods. The date are then synthesised and analysed to produce a listing of issues that become the subject of resource management plans. These are priorized and costed and then compiled in a Park Conservation Plan which on approval becomes the basis for resource management activities for a period normally of five years. The execution of these individual plans with ongoing monitoring and appropriate feedback mechanisms are the remaining components of the NRMP. Senior management approval is required at various times during the process. This feature lends credence to the NRMP by establishing a hierarchy of accountability for the human and fiscal resources committed to natural resource management.

The importance of the NRMP extends beyond natural resource management. Its outputs are designed to be used as inputs in the planning activities of existing as well as proposed parks. Also since the outputs are useful as references for interpretive programs the process is well integrated into the driving mechanisms for most other activities in Canada's national parks.

Resource Management Responsibilities. Atlantic national parks are anomalous in that each has a resource management specialist. However, in the Atlantic Region as in other regions, resource management issues at the park level are the responsibility of the park warden service. Within the National Parks Branch there are 405 positions assigned to resource conservation. This represents $8 \%$ of the Parks Canada person years complement and it includes all of the warden service positions that also hold the responsibility for public safety, public relations, and law enforcement. Each regional office (there are five: Western, Prairie, Ontario, Quebec, and Atlantic) has an average eight positions dedicated to resource conservation and 14 more work out of headquarters. In the current fiscal year, $7 \%$ of Parks Canada's budget of $\$ 303$ million is earmarked for spending on resource conservation.

\section{Resource Management - An Example}

Fire Management. The use of fire to achieve natural resource objectives illustrates well how the above framework functions. At the inception of the national park system fire suppression was a preoccupation. Frequent fires caused by railroads and the widely held tenet of the day that all fires must be fought until extinguished spurred the National Park Branch to lead the country in developing new techniques and equipment to combat fires. However as other issues began to preoccupy park managers and the incidence of fire declined so did Parks Canada's fire management capabilities. Moreover, provincial agencies proved to be dependable sources of assistance when they were needed.

The 1979 Parks Canada Policy dealing with resource management meant that fire management could no longer be ignored. In the six ensuing years caution has dominated implementation of the Parks Canada Policy on fire, not only because the fire policy called for capabilities that had waned in a number of parks but also because the dangers associated with fire. Furthermore there was a concern about proceeding too rapidly or without an advance publicity in view of the widespread Smokey Bear messages and the large Canadian vested interest in the woodfibre industry.

To ease into the new fire management policy, it was originally proposed to use pilot parks. A more widespread approach is now favored and a new management directive is being approved. All parks will now have as their first priority the development of a fire suppression capability. Only when this exists can the use of fire be considered. Also, the danger of fire is to be publicized in concert with fire prevention programs 
operating in adjoining jurisdictions. Parks Canada as a member of the Canadian Interagency Forest Fire Centre will also share in the fire suppression tasks and responsibilities of the other member organizations. It differs little with other land management agencies in Canada.

There is a difference, however, when a park embarks on a program of prescribed burning that may incorporate both planned and unplanned ignitions to perpetuate particular plant populations. Defining the objectives for burning and then the timing and the actual procedures for prescribed burns to achieve such objectives is a major concern. The concern is tempered by the fact that natural resource management initiatives in a national park are subject to the checks of approved management directives. For example, the fire management directive specifies that before fire can be used it must be preceeded by the application of the NRMP. Thus, if there is a role for fire to play in a park it will be defined, planned for, and eventually accommodated using an approved management procedure. Specifically, vegetation within a park dependent on periodic recycling by fire will be identified as an issue and a plan prepared for its management. Such a plan will specify the objectives for the vegetation and how these are to be achieved. When fire is to be used the details of its use will be incorporated in the park's fire management plan.

\section{Conclusions}

The first 100 years of park policy shows its tendency to change. Future policies will depend in part on the pressures exerted by groups and individuals interested in Canada's national parks. The interest traditionally anchored either in the conservation's or the developer's outlooks has forged our present park system and will probably continue to influence its future directions. However, if national parks are to achieve a measure of success in conserving elements of Canada's evolving landscapes a third voice will need to be heard. The professional resource managers will have to moderate and at times override the other essentially opposite viewpoints.

National parks in Canada and for that matter elsewhere in the world are leaving the passive management phase for the active management phase. The transition is occuring at varying rates. The parks with a history of natural process tampering or those turned into islands by the obviously differing adjoining land uses are at the crossroads of changing management styles. The continued conservation of evolving natural ecosystems in such parks depends on active management being undertaken. Some find a plunge into new waters difficult particularly when one hitherto lived with the principle of benign neglect and budgeted human and fiscal resources accordingly.

Professional resource managers can influence resource management in national parks. The fact that Parks Canada chooses to contract out or consider proposals for inputs at the technical level in the Natural Resources Management Process provides a direct avenue for influence. Although formulating park policy is a Parks Canada's responsibility, it is dependant on reasoned and sound advice. The professional resource manager and his researcher colleagues have a weighty responsibility in this regard. They have an understanding of the shortcomings, pitfalls and chances of success of management policies. Having this knowledge and not sharing it has grave ramifications. At stake are the reasons we are celebrating the Parks Canada Centennial: the heritage resources that are dedicated for future Canadians.

\section{Woodlot Service (1978) Ltd.}

"All Matters Pertalning to Forestry"

GORDON B. YOUNG, B.Sc.F., M.F.

Registered Professional Forester

320 Maple Street

Fredericton, N.B.
Bus.: 506-472-3396

Home: $506-472-7721$ 


\title{
Forest Pest Control Policies and Programs in Québec, New Brunswick and Maine
}

New England states and eastern Canadian provinces share some common forest pest control problems including the current spruce budworm outbreak. Over the years it has been possible to trace technical developments of the control programs and timber losses suffreed by individual provinces and states. Yet the economics and policies surrounding spruce budworm control have not been reported in a way that enables one to observe and understand the degree of coordination between government and industry in Canada and the U.S.A. To promote understanding of this vital subject, the CIF Working Group \#8 - Economics and Policy and SAF Working Group on Economics, Policy and Law held a joint meeting at the International Forest Congress at Québec City August, 1984. The objective of the meeting was to examine the "Economics, investment returns and public policy on forest pest control programs in New England and Canada, including the question: with major forest losses to insects in eastern U.S.A. and Canada, what are the public and private investment strategies at work (state/provincial, federal, private) and what are the results in terms of timber supply?" Two Canadian (J.C. Mercier and D.D. Lockhart) and two American authors ( $T$. Rumpf and G. Williams) presented the following papers and provided an informative panel session.

Patrick Duffy, RPF

Chairman, CIF Working Group \#8 Economics and Policy

\section{Protection of the Forest: A Social and Economic Imperative ${ }^{1}$}

\author{
by
}

Jean-Claude Mercier ${ }^{2}$

\begin{abstract}
The forest products sector is a vital segment of Quebec's economy. Until recently this sector was supported by abundant resources. Today, the situation has changed. Resource shortages could soon develop in certain regions. Even if forest management is increased to moderate these shortages, the necessity to protect the forest will not diminish. On the contrary, investments cannot be made without adequate protection programs.
\end{abstract}

Protection programs are not new. Fire protection was initiated in the early 1950 s and has since made considerable progress.

Losses from the current spruce budworm epidemic support the necessity to protect forests from insects. Insect control strategies and techniques have improved and will continue to improve in response to public pressure concerning the use of chemicals in the forest. As foresters, our challenge is not only to protect the forest but to inform the public of the necessity of protection to maintain our economic and social well being.

\section{Résumé}

Le secteur des produits forestiers est un segment vital pour l'économie québécoise. Jusqu'à tout récemment, d'abondantes ressources supportaient ce secteur mais des pénuries pourraient bientôt survenir dans certaines régions. Même si ces pénuries ont été tempérées par l'aménagement forestiers, la nécessité de protéger les forêts ne diminuera pas pour autant. Au contraire, des investissements ne peuvent être faits sans des programmes de protection adéquats.

Les programmes de protection ne sont pas récents. La protection contre les feux de forêts a commencé au début des années 50 et a progressé considérablement depuis lors.

Les pertes causées par l'épidémie actuelle de la tordeuse des bourgeons de l'épinette nous oblige à protéger les forêts contre les insectes. Les stratégies et les techniciens de protection se sont améliorées et s'amélioreront davantage afin de répondre aux pressions du public vis-à-vis l'utilisation des insecticides chimiques en milieu forestier. Comme forestiers, notre défit n'est pas seulement de protéger la forêt, mais d'informer le public sur la nécessité de le faire si on désire maintenir notre bien-être social et économique.

TPaper given at the International Forest Congress held at Quebec on August 7 1984

2Associate Deputy Minister, Department of Energy and Resources, Québec. Quebec. (Mr. Mercier has since become Associate Deputy Minister for the federal Ministry of State (Forestry). 